\title{
A FANTASIA ENQUANTO RITUAL E APELO PUBLICITÁRIO: UMA PROPOSTA DE ANÁLISE INTERTEXTUAL
}

\section{Fantasy as ritual and advertising appeal: an analysis of proposal intertextual}

\section{La fantasia como ritual y llamada publicitária: un análisis de la propuesta intertexual}

\author{
Susana Silva ${ }^{1}$ \\ Rui Torres ${ }^{2}$
}

\section{Resumo}

Este artigo aborda a fantasia enquanto uma dimensão de evasão para onde o indivíduo se projecta, através da promessa idílica do consumo feita pela publicidade. A análise de alguns anúncios demonstra de que forma a intertextualidade surge como uma estratégia privilegiada que convoca o leitor ao texto publicitário, remetendo-o para um universo de referências e textos inscritos na sua memória e na sua cultura, estimulando a imaginação e o despertar da fantasia.

Palavras-chave: publicidade, fantasia, intertextualidade

\begin{abstract}
This article addresses fantasy as a dimension of escape where to the individual projects himself, through the idyllic promise of consumption made by advertising. The analysis of some adverts evidences how intertextuality emerges as a privileged strategy that invites the reader to the advertising text, sending him to a universe of texts and references inscribed in his memory and in his culture, stimulating the imagination and the awakening of fantasy.
\end{abstract}

Key-words: advertising, fantasy, intertextualility

\section{Resumen}

Este artículo aborda la fantasía como una dimensión de evasión donde se proyecta el individuo, por medio de la promesa idílica del consumo hecha por la publicidad. El análisis

\footnotetext{
${ }^{1}$ Susana Silva, Mestre em Ciências da Comunicação - ramo de Marketing e Publicidade, pela Universidade Fernando Pessoa. Contactos: 1740@ufp.edu.pt; telemóvel: +351965414195.

${ }^{2}$ Rui Torres, Professor Associado da Faculdade de Ciências Humanas e Sociais da Universidade Fernando Pessoa, Porto. Investigador do CECLICO - Centro de Estudos Culturais, da Linguagem e do Comportamento. Contactos: rtorres@ufp.edu.pt.
} 
A fantasia enquanto ritual e apelo publicitário: uma proposta de análise intertextual de Susana Silva e Rui Torres

de algunos anuncios muestra cómo la intertextualidad surge como una estrategia privilegiada que invita el lector al texto publicitario, remitiéndolo a un universo de referencias y textos inscritos en su memoria y su cultura, estimulando la imaginación y el despertar de la fantasía.

Palabras-clave: publicidad, fantasía, intertextualidad.

\section{O RITUAL DA FANTASIA: OS APELOS À EVASÃO}

A fantasia pode ser descrita como uma faculdade livre, que depende das relações que o pensamento cria com o que conhece, definindo-se como "tudo o que antes não existia, ainda que irrealizável” (Munari 2007:11), ou, numa vertente sociológica, pode ser entendida enquanto espaço de projecção de desejos não satisfeitos (Filho 1988). Na publicidade, a fantasia expressa-se pelos códigos de linguagem que suscitam um esforço imaginativo por parte do receptor, num ritual de evasão em que se tecem os sonhos do consumo. Pelas referências intertextuais fornecidas pelo anúncio, o leitor é convidado a agarrar o curso de sentido proposto pelo texto, a reconhecê-lo e a completá-lo de acordo com as suas próprias experiências e conhecimentos. Reconhece-se que esta fantasia possa traduzir momentos de descontracção essenciais ao bem-estar do indivíduo, na medida em que o libera momentaneamente das obrigações do quotidiano e lhe permite projectar as suas próprias fantasias e desejos pessoais. Contudo, quando encarada numa perspectiva simbólica de dependência e de substituição, entende-se que a fantasia possa transformar-se num processo de subversão, remetendo o indivíduo para um espaço de falsa utopia, na busca do inatingível e distanciado de si próprio.

\subsection{Os Caminhos Da Fantasia}

A fantasia expressa-se de formas que apelam aos sentidos e à imaginação. Martin (2004) demonstra como o imaginário é evocado e tematizado nas experiências de consumo, tendo por base quinze participantes de um jogo de cartas temático. A imaginação é entendida enquanto fantasia, expressão do pensamento e criatividade. O imaginário parte da realidade mas, ao libertar-se para além do conhecido, funciona como a sua negação, como fantasia, ou seja, como fuga. Para o participante tipificado neste estudo (2004), a fantasia é inspirada nas suas vivências de infância e tem início no momento de preparação do jogo, que é encarado como um ritual de descontracção. Neste hobby, ao contrário da 
A fantasia enquanto ritual e apelo publicitário: uma proposta de análise intertextual de Susana Silva e Rui Torres

ficção, o curso dos acontecimentos não está determinado e o participante é activo na evolução do imaginário. Ao encarnar uma personagem, o sujeito adquire os seus poderes mágicos e lidera a fantasia. O sujeito evoca o imaginário a partir das imagens das cartas e a fantasia é orientada num sentido de prazer que gera significado na sua vida real. O mesmo se passa nas situações de consumo.

A exposição de Munari (2007) revela as técnicas subjacentes à expressão da fantasia, da invenção e da criatividade. Uma delas é a inversão, que consiste na permuta de uma situação e no uso dos contrários. Pode ser também aplicada a multiplicação das partes de um conjunto, sem alteração das suas funções. A mudança dos elementos habituais num objecto, pessoa ou contexto, traduzem uma quebra com o expectável, resultando numa mutação ou numa ausência de sentido. Essa mudança pode aplicar-se à cor, à matéria, ao lugar, à função, ao movimento, ao peso e à dimensão. A técnica de fusão de elementos diferentes num único corpo pode ser ilustrada pela criação de monstros no cinema, como é o caso do filme A Mosca (1957), protagonizado por Jeff Goldblum, e das sereias, referidos por Munari (2007). As relações entre relações implicam a combinação de várias práticas, ou seja, mudanças e substituições que, combinadas entre si, geram situações mais complexas.

A fantasia não tem limites e, ao contrário da ficção, permite que o sujeito comande os seus próprios desejos de modo a produzirem significado na vida real. Enquanto técnica e faculdade do pensamento, deve ser estimulada e, no discurso publicitário, expressa-se pelas formas como o anúncio joga com o imaginário do receptor.

\subsection{Imaginário E Fantasia: As Tendências Utópicas Do Discurso Publicitário}

A publicidade é o discurso do superlativo do consumo: do mais e do melhor, dos estilos de vida ideais e da abolição de barreiras e de imperfeições. Tal estado de deslumbramento, se bem que inverosímil num mundo real, imagina-se alcançável num plano de fantasia, ao qual o sujeito é chamado. Os desejos efectivos são canalizados para as promessas do consumo, concebendo um indivíduo de identidade volátil que se transforma à medida das ofertas do mercado, numa constante recriação de si próprio. Esta proposta de recriação individual revela um sujeito fragmentado que se compõe à medida dos objectos de desejo, sob forma de "identikit" (Williamson 1994:70), ou comparável a "uma identidade esquizofrénica em que em que cada um pode ser várias coisas ao mesmo tempo" (Gunster 2007:220). Alienado de si, o sujeito é simultaneamente produto e 
A fantasia enquanto ritual e apelo publicitário: uma proposta de análise intertextual de Susana Silva e Rui Torres

consumidor: "we consume, buy the produt, yet, we are the product" (Williamson 1994:70). Este é o perfil do consumidor pós-moderno dos espaços urbanos, traçado por Hannigan (1998); um indivíduo livre de ligações, mas preso na construção de identidades móveis (que se alteram e alternam com novos símbolos), viciado em representações de prazer.

Os estados de fantasia são frequentemente associados a uma forma de libertação ou de fuga à realidade. Efectivamente, a publicidade cultiva o desejo do consumidor se projectar numa outra dimensão, mediante a promessa de um cenário idílico. Na sua postura crítica face aos efeitos da publicidade, Pollay (1986:26) afirma que esta promove um estilo de vida utópico, convocando o indivíduo a um limbo onde se confundem realidade e fantasia, reduzindo as suas defesas e a sua capacidade crítica. Esta dimensão indistinta assemelha-se ao "lúcido realismo dos sonhos" de que fala Volli (2003:9), na medida em que é percebida pelo consumidor não como ficção, mas como uma realidade imaginada. Por outro lado, Gunster associa a fantasia da publicidade à utopia e às formas idealizadas de vida, enquanto "santuário" (2007:212) aparte das constrições do quotidiano e das racionalizações do capitalismo.

Embora sirva como escape momentâneo, esta face idílica da publicidade pode gerar percepções deturpadas da realidade, implicando efeitos mais duradouros. Richins (1991) concluiu que as imagens da publicidade afectam os padrões de comparação e a percepção de realização e satisfação pessoal. Os resultados deste estudo atestam que campanhas com imagens de extrema atractividade, embora aparentemente apelativas, poderão gerar sentimentos negativos no consumidor, defraudando a sua auto-estima e alterando a sua percepção. Como sustenta esta investigadora (1991:71), o indivíduo é atormentado pela consciência de nunca atingir os estados de perfeição retratados nas imagens mediáticas. A publicidade manipula a realidade dos produtos, apresentando-os como personagens de ficção que resgatam o indivíduo da sua vida, para uma plataforma de poder, liberdade e identificação, como se verifica pelo título do anúncio 1, analisado mais à frente: "Chegou o Cartão White. O cartão que vai colorir a sua vida". Como referem Leiss, Kline, Jhally e Botterill, os objectos revestem-se de qualidades sociais e humanas e "servem-nos de veículo para a fantasia e reflexão" (2005:4). Esta crença no poder dos objectos eleva-os à condição de mitos, que mantêm o indivíduo num constante desafio ideológico de crer nele enquanto tal ou de desvendá-lo sob pena de o destruir (Barthes 1957:223).

Os automóveis são dos exemplos mais flagrantes deste apelo à fantasia e à fuga e, como é referido por Freitas, alvo de conotações sexuais: "cars have traditionally been seen as extensions of male virility (...); as a powerful way of attracting beautiful women; and as 
A fantasia enquanto ritual e apelo publicitário: uma proposta de análise intertextual de Susana Silva e Rui Torres

a privileged place for teenage or extra-marital sex" (Freitas 2008:59). Como defende também Houdayer, o automóvel proporciona a ideia de desafio e liberdade, mas também de espectáculo e erotismo: "por trás da certeza de um certo conforto, esconde-se a embriaguez da velocidade, sinal de sensações fortes, da ultrapassagem de limites, do erotismo; distante do cotidiano" (2006:102). A pesquisa dos temas utópicos da publicidade a automóveis feita por Gunster (2007) configura os anúncios enquanto fuga às relações do capitalismo por via do próprio consumo. Genericamente, as descrições utilitárias dos automóveis são preteridas por descrições extasiadas da capacidade de o automóvel transportar o indivíduo a um lugar ou forma de ser para além da razão (2007:221). A campanha da agência Leo Burnett para o novo Alfa Romeo Giulietta (Imagem 1), lançado em 2010, ilustra de que forma são feitas estas associações, pela relação intertextual que é criada com o leitor.

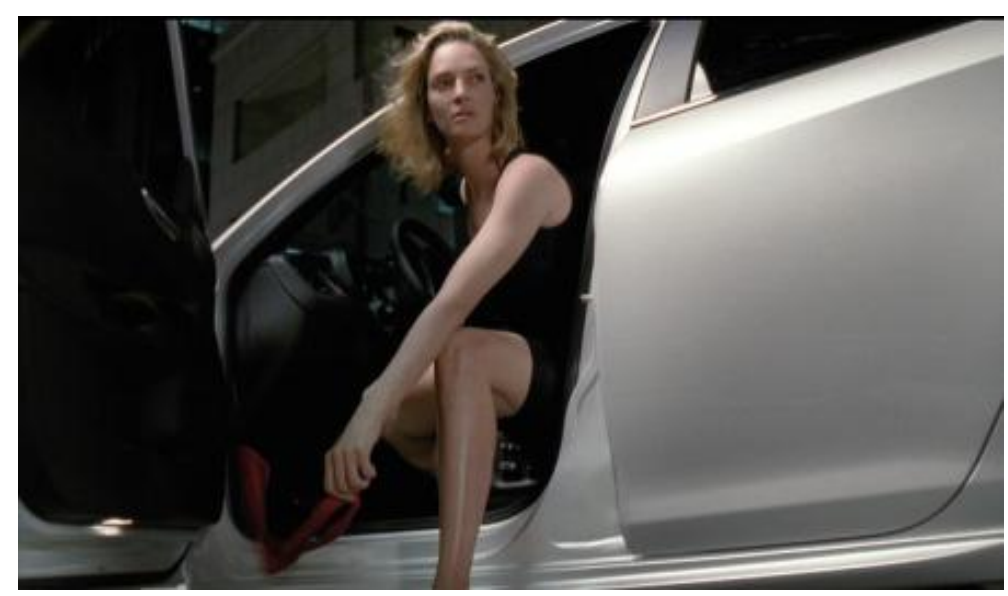

Fig. 1 - Alfa Romeo Giulietta

O primeiro passo dá-se pela junção subtil do nome do modelo ao nome da marca, proporcionando uma primeira referência à obra de Shakespeare "Romeu e Julieta". O anúncio $^{3}$ é protagonizado pela actriz Uma Thurman, reconhecida do público pelo seu desempenho em filmes como Pulp Fiction e Kill Bill, simbolizando características de beleza e força que se unem, no panorama do anúncio, à afirmação de pureza e tecnologia que neste quarteto de qualidades a fazem confundir-se com o automóvel que personifica. A associação literária completa-se com a frase shakespeariana de "A tempestade", que

\footnotetext{
${ }^{3}$ Este anúncio pode ser visualizado no seguinte endereço: www.youtube.com/watch?v=sFE2CIYgeb4
} 
A fantasia enquanto ritual e apelo publicitário: uma proposta de análise intertextual de Susana Silva e Rui Torres

encerra o anúncio de forma a transportar o leitor para além do utilitarismo do objecto: "somos feitos da mesma matéria de que são feitos os sonhos".

Contudo, esta ideia de fuga e de realização estabelece um paradoxo de libertação e captura. Trata-se de um escape fictício, uma vez que a sua operacionalização remete para o estado de aprisionamento de que tentou fugir, mudando apenas a fachada. Gunster (2007:232) adverte que os efeitos destes temas utópicos acabam por aprisionar o indivíduo nas constrições de que tentou escapar: o sujeito vê-se capturado pelo prazer que apenas o objecto pode proporcionar. Esta perspectiva assemelha-se à de Filho, que considera que o sentido de realização histórica suscitado pela utopia depende do modelo económico: "a realização da utopia se dá pela via económica, especialmente no capitalismo" (1988:23). O futuro e a verdadeira essência da utopia ficam comprometidos pelo facto desta estar vinculada apenas ao mundo dos objectos de que tanto procura escapar, o que desvirtua o próprio sentido utópico do consumo, como é retratado por Gunster (2007:234).

Considerados os seus efeitos benéficos, assume-se que a fantasia pode proporcionar momentos de evasão positivos, como sentimentos de descontracção, de prazer e de pertença. Enquanto figura do pensamento, produz conteúdos que assumem formas inéditas pela via da imaginação. Porém, enquanto apelo constante da publicidade, pode ter consequências a ponderar: por um lado, intervém com uma multiplicidade de imagens que apelam ao desdobramento da identidade individual; por outro, o retrato idealista que cria, supõe uma impossibilidade de alcance que, uma vez desfeito, devolve o indivíduo à sua realidade, com um duplo sentido de frustração.

\subsection{As Fantasias (E Perversões) Do Consumo}

A fantasia é indissociável do consumo, uma vez que este decorre num plano simbólico. Como recorda Fitchett, "desire, fantasy and imagination are integral aspects of the consumption experience" (2004:285). Contudo, apesar de apelativa, considera-se que a repetição exaustiva da fantasia ou a sua generalização a várias dimensões da vida contemporânea pode anunciar uma forma de dependência e de perversão, caracterizada por vários autores.

No livro Fantasy City, Hannigan (1998) ilustra a urbe americana como um espaço em que o entretenimento e a tecnologia funcionam como uma dimensão de fantasia pouco democrática, quer pela acessibilidade limitada, quer pelas barreiras de custo. A transformação do entretenimento comercial nas grandes cidades da América, que ocorreu 
A fantasia enquanto ritual e apelo publicitário: uma proposta de análise intertextual de Susana Silva e Rui Torres

no período de 1885 e 1930, e a emergência de uma nova cultura pop estão nas origens do que hoje se considera o ambiente de fantasia urbano. A publicidade sempre contribuiu para a cidade de fantasia - por exemplo, com os seus sinais luminosos no início do século XX que funcionavam como espectáculo por si mesmos (Hannigan 1998:90). Na análise deste autor (1998), a partir dos anos 90 do século XX, o entretenimento enquanto tendência e produto de consumo estendeu-se às compras, à restauração e até mesmo à educação e à cultura. Este novo espaço demarca-se pelo valor atribuído aos produtos e marcas, pelo simulacro de experiências e pela ambiência afectiva gerada pelo consumo de entretenimento. A criação de fantasias controladas transmite uma aparência fantástica de realidade, mas não passa de uma simulação pois, como refere Hannigan (1998:72), implica que se esqueçam ou ultrapassem as origens reais e históricas.

As relações simbólicas do consumo destacam o consumidor não apenas como um ser racional, que orienta as suas decisões em função de aspectos objectivos, mas sobretudo enquanto um ser afectivo, que se guia pelo instinto e pela emoção. Deixando à margem a função utilitária dos produtos, verifica-se que é pela sua função simbólica, promovida pelo discurso publicitário, que o consumidor é transportado a um mundo de sonho, onde é senhor e escravo dos seus desejos. O modelo experiencial de Holbrook e Hirschman (1982) centra-se nas reacções de excitação, nos conteúdos latentes, na emoção e no prazer que o indivíduo retira do uso do produto e nas fantasias evocadas, concluindo que o consumo é vivenciado como um momento de prazer e fantasia: "this type of consumption seeks fun, amusement, fantasy, arousal, sensory stimulation and enjoyment" (1982:135). Tendo por base o tópico de cirurgia estética electiva, o estudo de Schouten (1991) valida igualmente a importância do consumo simbólico e experiencial nas situações de transição do "eu" dos indivíduos, uma vez que assiste à construção e manutenção de novos papéis e identidades. Nomeadamente, este investigador conclui que as fantasias românticas elaboradas pelos participantes neste estudo resultam frequentemente de imagens promovidas pela cultura popular e podem desempenhar um papel importante na elaboração do "eu" ideal, proporcionando, através do consumo simbólico, uma aproximação entre o real e o ideal.

Estes aspectos afectivos do consumo, que tanto parece unir pessoas e objectos de desejo, são fundamentais para se perceber como é que as fantasias se assemelham a uma forma de doença, dependência ou de perversão. Nomeadamente, Fitchett (2004) e Kehl (2008) associam o consumo às ideologias do Marquês de Sade. A proposta de Fitchett (2004) não sustenta que os indivíduos são sádicos quando participam em experiências de consumo, mas fornece uma abordagem cultural do consumo pós-moderno ao concluir que 
A fantasia enquanto ritual e apelo publicitário: uma proposta de análise intertextual de Susana Silva e Rui Torres

os textos de Sade proporcionam um contexto de prazer e excitação em que os consumidores desejam participar (Fitchett 2004:303). Segundo Kehl (2008), o imperativo publicitário de gozo imediato e eterno assemelha-se às fantasias eróticas do Marquês de Sade. A publicidade é a linguagem dos objectos e do prazer, quer pela fantasia de bem-estar que propõe através da especulação de mercadorias, quer por ser em si própria "pura imagem de gozo, puro fetiche" (Kehl 2008:31). Não obstante, esta fantasia de prazer inconsequente gerada pelo estímulo publicitário pode conduzir o indivíduo a uma condição de subjugação e de dependência, em que o consumismo é comparado a uma situação de doença, de histeria (Kehl 2008). Na mesma orientação temática, Houdayer (2006) equipara a publicidade a uma droga que seduz o consumidor. Em ambas se revê o mesmo valor de ameaça e dependência. Na abordagem simbólica de Houdayer (2006), o discurso publicitário implica elementos comunicacionais semelhantes a comportamentos de risco, já anunciado por Pollay (1986), quer pela noção de desafio e de superação dos limites, que se expressam pelos ideais de conquista, de viagem e ousadia, quer pelo uso de substâncias artificiais para promover estilos de vida. Embora se considere que a posição de Houdayer (2006) é extremista, no sentido que destitui o consumidor de sentido crítico e amplia os efeitos da publicidade a um nível de intoxicação e decadência, pode perceber-se, na sua abordagem simbólica, os elementos de ligação intertextual entre os códigos da droga e o discurso publicitário. O universo de referências intertextuais do receptor é activado pelo uso de expressões e imagens, que habilmente reproduzem determinadas experiências ou estados de espírito. Pelo fascínio e pelo culto do ego, pela promessa de transgressão em forma de libertação, brinca com o imaginário e com as fantasias do consumidor. Nesta perspectiva, pode encontrar-se a seguinte premissa: tal como a droga, a publicidade fornece estados que alternam entre delírio (desejos, impulsos hedonistas) e lucidez (percepção dos actos de consumo, eventuais sentimentos de frustração), resultando em estados de constante sujeição. O consumidor é um dependente, retoma sempre o ciclo, porque o simbolismo (o delírio do imaginário) é superior à lógica. A repetição da mensagem publicitária promove a habituação, a reincidência, a cedência do social ao imaginário.

Neste sentido, a fantasia pode assumir-se enquanto liberdade ou enquanto aprisionamento. Como sustenta Filho (1988), a fantasia tanto pode significar emancipação, enquanto força transformadora que estimula a realização dos sonhos, como repressão, ao constituir-se como domínio de classe e imposição. Na sua forma coibitiva, nas palavras de Filho, "regrediente" (1988:26), a fantasia veste a forma de neurose, no sentido em que reporta aos desejos não realizados que se transformam em comportamentos neuróticos, 
A fantasia enquanto ritual e apelo publicitário: uma proposta de análise intertextual de Susana Silva e Rui Torres

sem se alcançar qualquer satisfação. Este parecer é partilhado por Kehl, que define a publicidade como um "mestre perverso" (2008:32) que domina o imaginário da sociedade consumista, traduzindo um conceito de neurose que se pode rever na sujeição consciente e voluntária do indivíduo às representações do consumo. Enquanto que o imperativo de Sade é libertação (Fitchett 2004, Kehl 2008), o neurótico é repressão, porque se submete a uma vontade que julga ser, mas nunca é a sua. A publicidade não oferece a possibilidade de um desejo livre e autónomo, mas cativa o consumidor, mediante uma proposta de prazer imaginado e fugaz, no desejo e na vontade que ela própria cria e obriga.

O escape proposto pela publicidade aufere, muitas vezes, uma carga sexual. Para Kehl a publicidade transforma meros produtos em objectos de desejo, que surgem na qualidade de fetiches, "como condição indispensável para fazer existir a relação sexual" (2008:28), promovendo a fantasia de união entre personagens dos anúncios e pessoas da vida real. De modo semelhante, Filho (1988) refere que a vida numa sociedade de massas faz com que o indivíduo se projecte de formas desenraizadas de um carácter social e humano. Pela televisão e pela publicidade, este aspira viver sensações que a sua vida real não lhe permite, nomeadamente, no domínio sexual: "a televisão possibilita uma vida real, uma prática de emoções, de sentimentos, de alegria e de tristezas, de sensações sexuais que a vida real não mostra de forma alguma" (Filho 1988:30). Os apelos à evasão e ao erotismo são exemplos do discurso publicitário a trabalhar o imaginário, numa falsa busca de liberdade e prazer irreflectido. Como refere Gunster (2007:221), o sujeito é convidado ao abandono do auto-controle e do bom senso pelo domínio da paixão e do instinto. A fantasia expressa-se, muitas vezes, pelo apelo ao amor e à luxúria, que, tal como recorda Kehl, é a paixão mais absoluta, "cuja realização requer que todos tenham o direito a gozar sobre todos, livre e indiscriminadamente" (2008:31).

O tema da fantasia será seguidamente representado no seu carácter intertextual pela análise semiótica de uma pequena amostra de anúncios. Deste modo, pretende-se demonstrar como a publicidade apela à evasão, numa apologia ao sonho e ao distanciamento da realidade, fazendo uso de referências que se inscrevem na mente do consumidor.

\subsection{A Representação Intertextual Dos Apelos À Fantasia: Análise De Anúncios}

Será aqui submetida uma amostra de 8 anúncios que permitem ilustrar a face intertextual dos apelos à fantasia, em publicidade. Esta análise debruça-se sobre a forma 
A fantasia enquanto ritual e apelo publicitário: uma proposta de análise intertextual de Susana Silva e Rui Torres

como textos, símbolos e referências se cruzam no texto publicitário, convocando o leitor a ingressar num escape momentâneo da realidade e a entrar numa dimensão mágica.

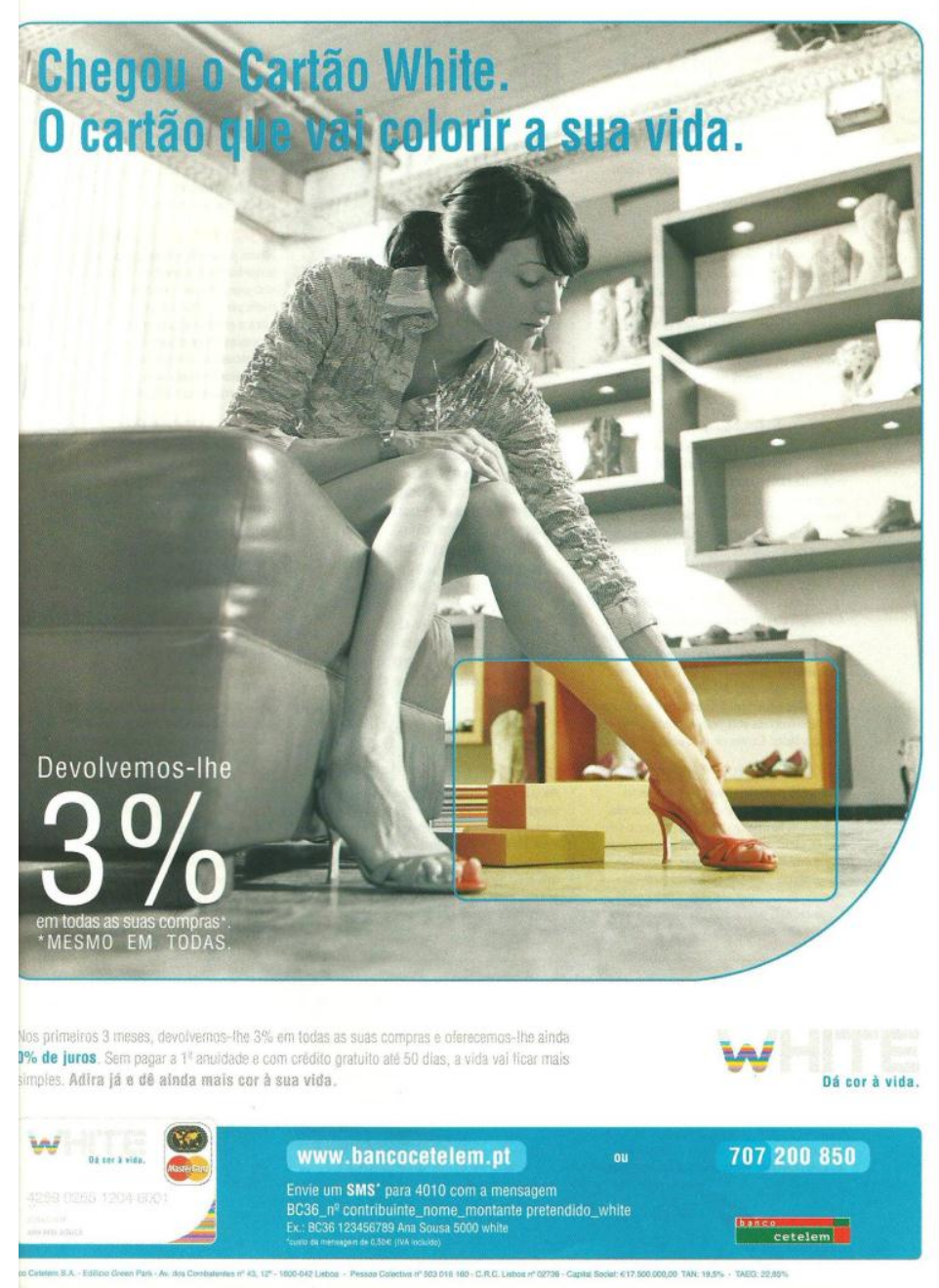

Fig. 2 - Anúncio 1: Cartão White

$\mathrm{O}$ produto surge na publicidade enquanto entidade transformadora, com capacidades mágicas de criar prazer e felicidade. Neste anúncio ${ }^{4}$, o benefício do crédito baseia-se na premissa de que a vida da pessoa é menos valorizada, face ao que seria através do acto de consumo. Como foi notado anteriormente, o título anuncia a chegada do Cartão White, sob forma de super-herói, declarando a promessa de mudança: "Chegou o cartão White. O cartão que vai colorir a sua vida".

Este antagonismo cromático (preto e branco/cores) e semântico (degenerescência/vitalidade; tristeza/alegria) funciona como jogo de contrários, num sentido de valorização do produto. É primordialmente representado pela imagem, que se

\footnotetext{
${ }^{4}$ Anúncio inserido na revista Activa, n. ${ }^{\text {184 }}$, edição de Março 2006: 167.
} 
A fantasia enquanto ritual e apelo publicitário: uma proposta de análise intertextual de Susana Silva e Rui Torres

caracteriza a preto e branco, excepto pelo pormenor que destaca a importância do objecto. Uma mulher está sentada no banco de uma sapataria e enquanto experimenta sapatos, percebe-se que apenas o cartão lhe preenche a alegria de satisfazer os seus desejos. Da monocromia geral, o olhar do leitor é atraído para um pequeno espaço preenchido com cor e energia: recortada na forma rectangular do cartão, destaca-se uma parte da imagem que exibe a vaidade feminina, em cores vivas e naturais. Quase como se tratasse de uma janela para a vida.

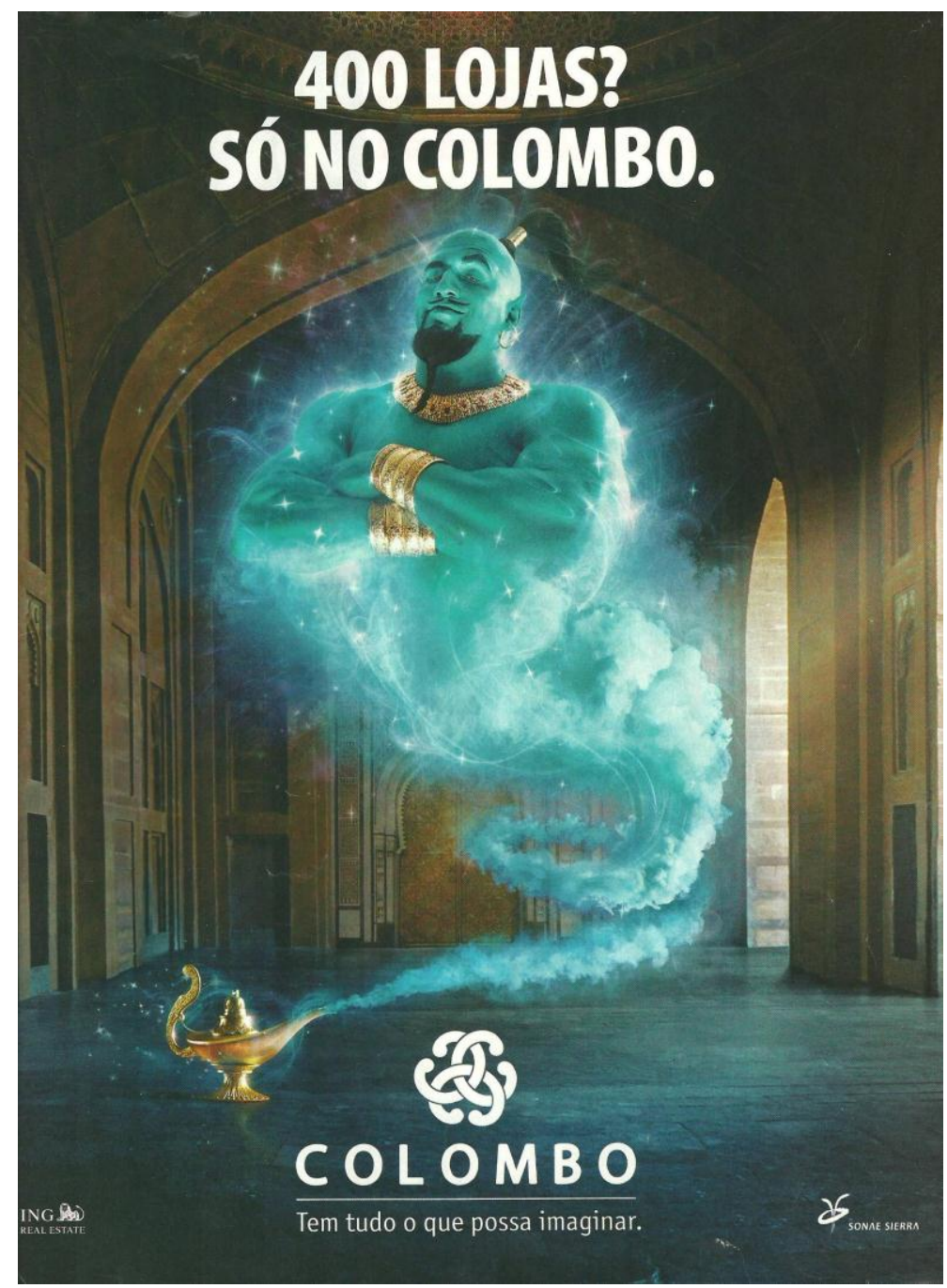

Fig. 3 - Anúncio 2: Colombo

Tal como refere Williamson (1994), a magia dos objectos em publicidade pode remeter para elementos iconográficos como génios em garrafas ou lâmpadas, ritos e feitiços, súbito crescimento ou miniaturização, acessórios ou figuras mágicas, entre outros. 
A fantasia enquanto ritual e apelo publicitário: uma proposta de análise intertextual de Susana Silva e Rui Torres

Como se encontra representado neste anúncio ${ }^{5}$, a fantasia é imediatamente evocada pela presença de símbolos pertencentes a um dos contos mais famosos da obra medieval árabe, As Mil e Uma Noites: Aladino e a Lâmpada Mágica. Tal como conta a história, a lamparina que Aladino procurava estava no interior de um jardim encantado, numa espécie de gruta ou caverna que continha muitos tesouros. Na imagem, a lâmpada de Aladino está a deixar soltar o génio que se assume enquanto personagem fictícia do conto. Este surge envolto em fumos mágicos, adornado por jóias, e de braços cruzados, como quem aguarda instruções sobre os desejos a realizar. O seu olhar é complacente mas de superioridade, uma vez que se dirige para baixo.

Intencionalmente, a figura de Aladino não se encontra representada no anúncio, uma vez que se trata do papel que o leitor é convidado a representar. O título "400 lojas? Só no Colombo" poderá representar uma fala da personagem, que se supõe dizer que o espaço comercial transcende as potencialidades mágicas do génio. O slogan, "Tem tudo o que possa imaginar" proporciona o trabalho do imaginário, dando sentido à evasão. $\mathrm{O}$ indivíduo é aliciado pelo poder da imaginação, dando forma a todas as suas vontades.

No conto, o génio realiza todos os desejos de Aladino, transformando-o em príncipe e em governador do seu reino. No anúncio, a mudança que se propõe, no plano do imaginário, representa igualmente uma transformação na realidade pessoal. O génio visa transformar o consumidor em príncipe dos seus desejos mas, desta vez, invertendo o sentido de maturidade. De adulto consciente, o consumidor é proposto retomar a forma de criança, que compõe a sua realidade ao modo de histórias infantis, num mero plano de fantasia. Este é também um exemplo de como a publicidade retrata a magia dos objectos, neste caso de forma marcadamente icónica.

\footnotetext{
${ }^{5}$ Anúncio inserido na revista Caras, n. ${ }^{\circ} 739$, edição de 10 de Outubro 2009: 135.
} 


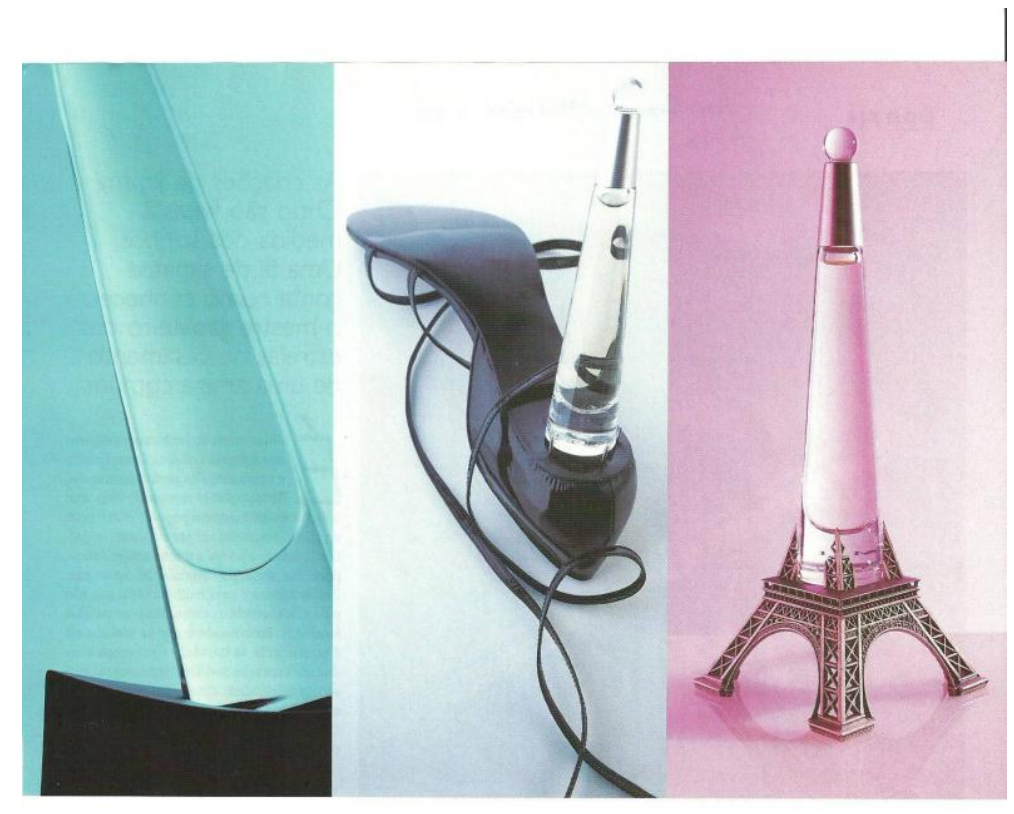

H I S T Ó R I A S

D E

\section{L' E A U D' I S S E Y}

I S S E Y M I Y A KE

Fig. 4 - Anúncio 3: Perfume L’Eau D’Issey

Sendo verdade que cada produto conta uma história, neste anúncio ${ }^{6}$ contam-se várias. A intertextualidade é aqui representada pelo resgate que o texto faz das referências ao mundo da arte e da cultura. O perfume assume-se como parte de uma história que é retratada visualmente através da sua ligação à arte e à sofisticação, completando-a e emprestando-lhe um cunho pessoal. Na sua forma cónica, assume-se como uma obra de arte, como o salto improvisado de um sapato de mulher, ou como a Torre Eiffel. A participação do produto na história é central, de modo a que a fantasia romântica que proporciona seja impensável sem a sua existência. O facto de a imagem do salto do sapato feminino se encontrar entre a reconstrução visual de uma obra de arte e de um monumento internacionalmente consagrado que se inscreve no repertório cultural do leitor, sugere que

\footnotetext{
${ }^{6}$ Anúncio inserido na revista Vogue Portugal, n. ${ }^{\circ}$ 30, edição de Abril 2005: 33.
} 
A fantasia enquanto ritual e apelo publicitário: uma proposta de análise intertextual de Susana Silva e Rui Torres

o perfume é igualmente um objecto de valor na arte da beleza feminina. O título "Histórias de L'Eau D’Issey” dá início à história do anúncio, que joga com a história do leitor.

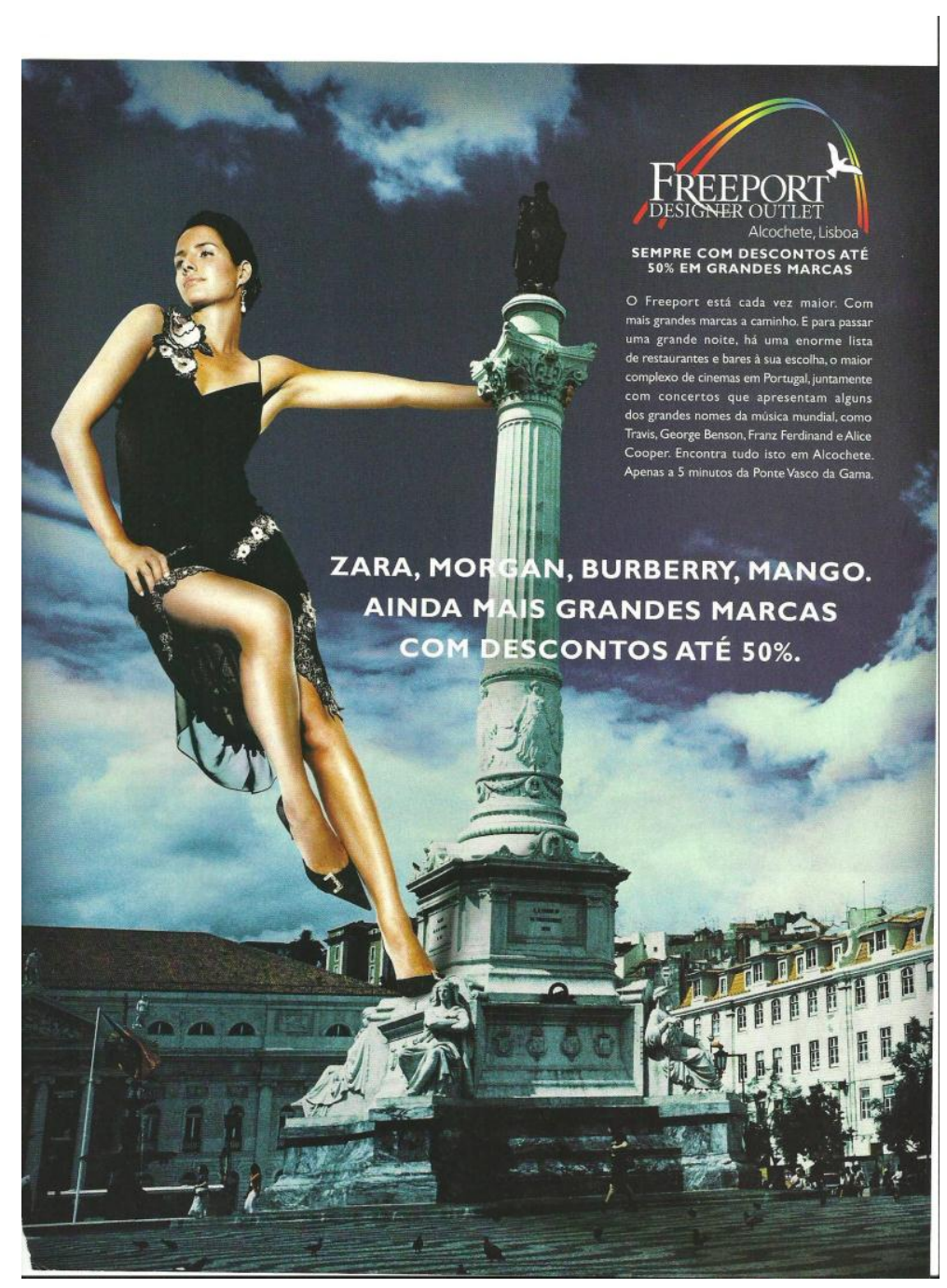

Fig. 5 - Anúncio 4: Freeport

Neste anúncio $^{7}$, reconhece-se a fantasia pela miniaturização referida por Williamson (1994) e pela técnica de mudança de dimensão, representada por Munari (2007), na ampliação irreal da personagem feminina. Descontraída e de aparência sofisticada, a mulher eleva-se sobre edifícios e pessoas, rodopiando sedutoramente à volta de um monumento, desfilando perante o olhar do leitor. Neste contexto, a mulher assume o poder, tanto pela dimensão desproporcional que lhe é conferida, como pela forma como expressa o seu domínio de sedução sobre a cidade reduzida a um tamanho liliputiano. A referência intertextual a Lilliput, ilha fictícia do romance As viagens de Gulliver, de

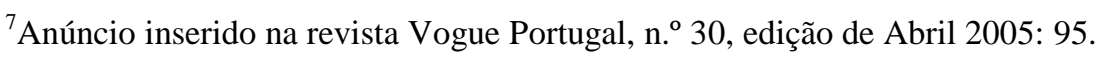


A fantasia enquanto ritual e apelo publicitário: uma proposta de análise intertextual de Susana Silva e Rui Torres

Jonathan Swift, evidencia-se pela forma como tanto a personagem do anúncio como a personagem do conto se deparam com pessoas de tamanho minúsculo, sendo tomadas por gigantes. Mais próxima do céu, mais próxima está de realizar os seus desejos.

O texto orienta o sentido da mensagem, em que a noção de grandiosidade se repete ao longo das frases. Trata-se de grandes descontos em "grandes marcas", em que o Freeport "está cada vez maior", "com mais grandes marcas a caminho", para passar "uma grande noite", com uma "enorme lista de restaurantes e bares", com "o maior complexo de cinemas em Portugal" e com os "grandes nomes da música mundial". Aqui se verifica também a tendência egocêntrica do consumo traduzida pelo discurso publicitário. Ou seja, no Freeport é tudo à grande... e à imagem de quem quer ser o maior.

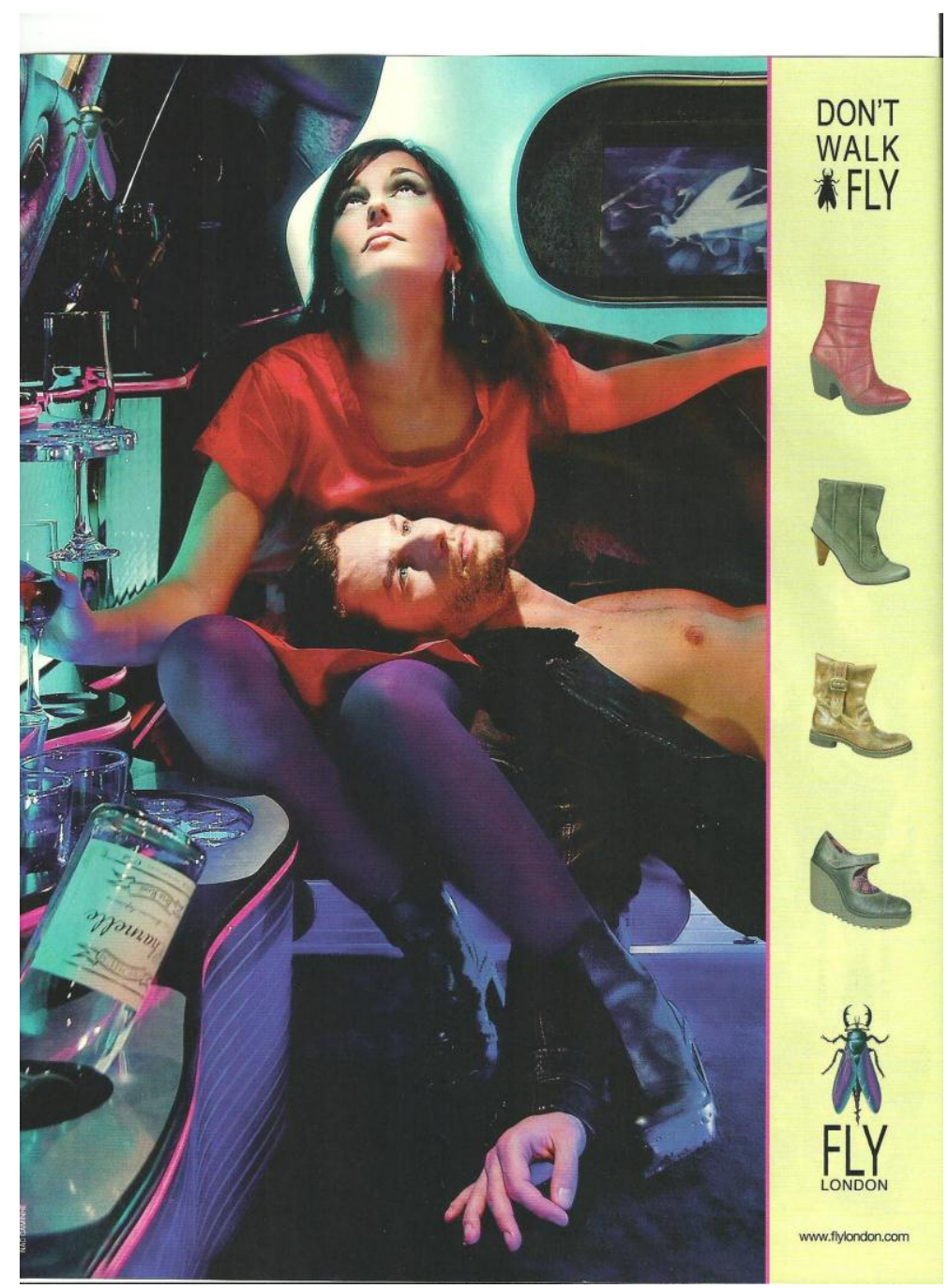

Fig. 6 - Anúncio 5: Fly 
A fantasia enquanto ritual e apelo publicitário: uma proposta de análise intertextual de Susana Silva e Rui Torres

A evasão retratada neste anúncio ${ }^{8}$ assemelha-se ao conceito de embriaguez ou de droga que seduz o consumidor, proposto por Houdayer (2006). Esta marca de calçado nacional traduz pela sua designação e pelo logo da mosca, a noção de voo, de leveza e de viagem. De acordo com Chevalier e Gheerbrant a mosca representa uma "busca incessante" (1997: 461, negrito no original). O uso do imperativo do slogan "Dont' walk, fly”, dita o comandar da acção e da adesão ao produto. Neste sentido, a marca faz associar a qualidade e o design do seu produto a um caminhar que se assemelha a um voo, mas, mais do que implicitamente, remete para um duplo sentido de viagem, de busca.

Nesta imagem, surge um casal que se encontra num lugar indefinido, que poderia ser, supostamente, um espaço de diversão nocturna ou, dando-se asas à imaginação, a cabine luxuosa de um avião particular. O homem encontra-se deitado, com a cabeça apoiada no colo da companheira, com a camisa desabotoada e com uma das mãos a pender para o chão. Ela segura distraidamente um copo, com o olhar voltado para cima, fixo em algo que não se permite ver. Ambos revelam um olhar alienado, sem destino, que não procura o leitor, mas que o atrai pela estranheza da situação. A prevalência de uma garrafa vazia e de vários copos aponta para o estado de intoxicação e de delírio apontado por Houdayer (2006). A viagem da Fly London não é tanto uma viagem para os pés como é para a mente. Quase sem ligação ao produto, excepto pela barra lateral em que surgem os vários modelos, o anúncio é mais uma sugestão de alucinação e de jornada ao desconhecido. O uso dos códigos do álcool e da droga revela-se singularmente pela imagem e pela força conotativa do slogan. Fica a cargo do leitor interpretar o destino deste voo.

\footnotetext{
${ }^{8}$ Anúncio inserido na revista Vogue Portugal, n. ${ }^{\circ} 83$, edição de Setembro 2009, Suplemento Moda Inverno 2009: 17.
} 


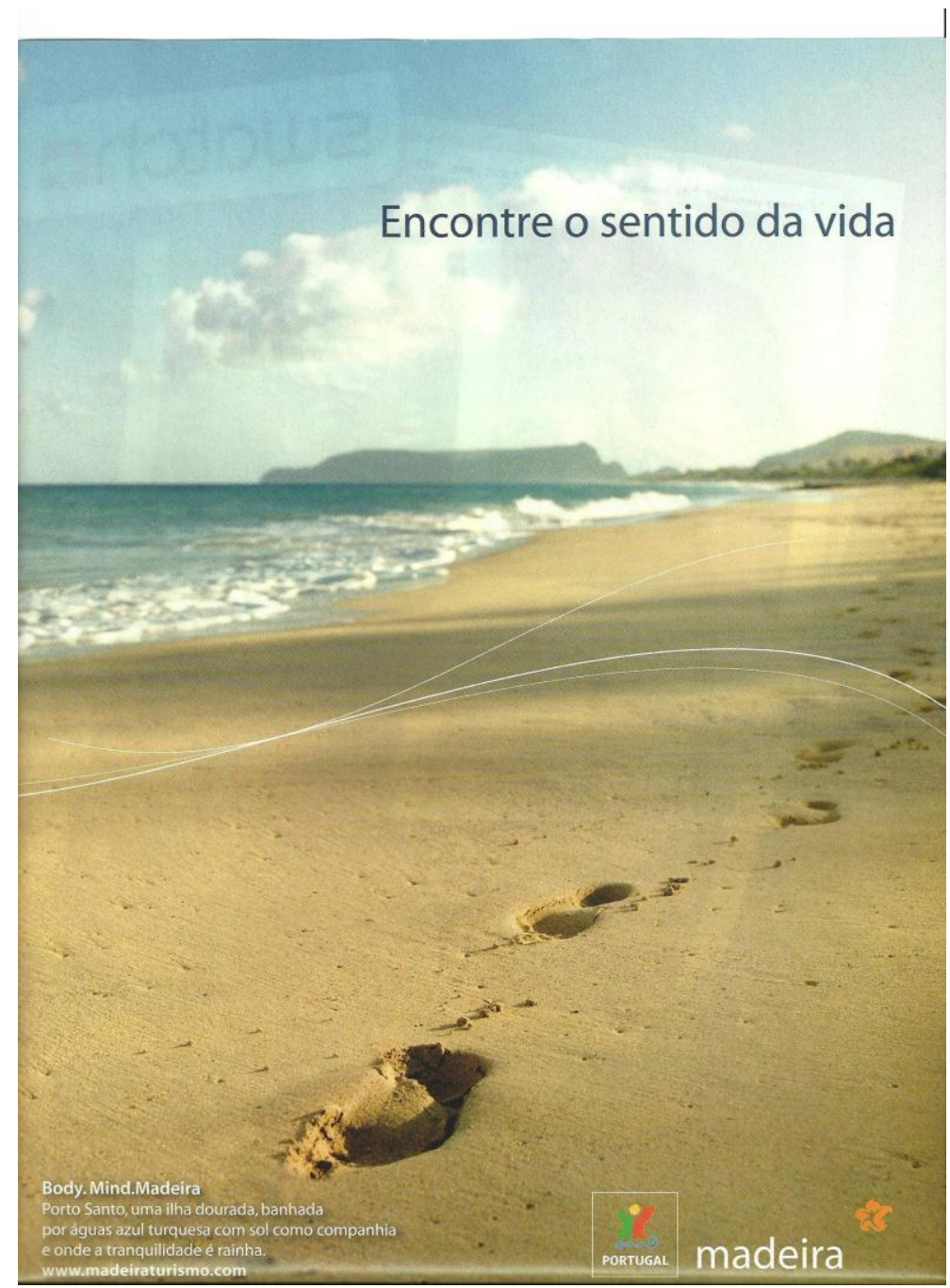

Fig. 7 - Anúncio 6: Turismo de Portugal (Madeira)

O apelo à fantasia é feito pela proposta de união espiritual. Neste anúncio ${ }^{9}$ do Turismo de Portugal, que promove a Ilha da Madeira, os trilhos da fantasia são preenchidos com símbolos que se cruzam, para que o leitor possa percorrê-los e completar o curso da significação.

Esta espiritualidade começa por ser expressa pelo título "Encontre o sentido da vida", que paira sobre uma imagem que evoca paz e serenidade. Como se verificou ao longo deste trabalho, a simbologia determina as suas relações entre o homem e o mundo, pelo que a necessidade de dar sentido à vida e às coisas preside desde sempre à finalidade existencial. A representação de uma praia deserta, banhada por um mar calmo, orienta o olhar através de um par de pegadas profundas gravadas na areia, até ao texto. Num enquadramento de meditação, o leitor poderá ser orientado no sentido da oração cristã

\footnotetext{
${ }^{9}$ Anúncio inserido na revista Activa, n. ${ }^{\circ}$ 186, edição de Maio 2006: 93.
} 
A fantasia enquanto ritual e apelo publicitário: uma proposta de análise intertextual de Susana Silva e Rui Torres

"Pegadas na areia", numa forma de intertextualidade pela adopção do discurso religioso, cuja moral determina que, ao reviver as cenas da sua vida, nos momentos difíceis a pessoa só avista um par de pegadas, uma vez que o seu peso está a ser suportado por Deus. A inexistência de personagens e a profundidade das pegadas funcionam como indícios para esta interpretação. A assinatura, "Body. Mind. Madeira" funciona como recriação da trilogia "Mente. Corpo. Alma", tirando partido do esquema rítmico proporcionado pela sucessão de palavras e pela aliteração do fonema "m" de "mind" e "Madeira". Neste sentido, a ilha assume-se não apenas enquanto produto turístico, mas na totalidade de elemento espiritual.

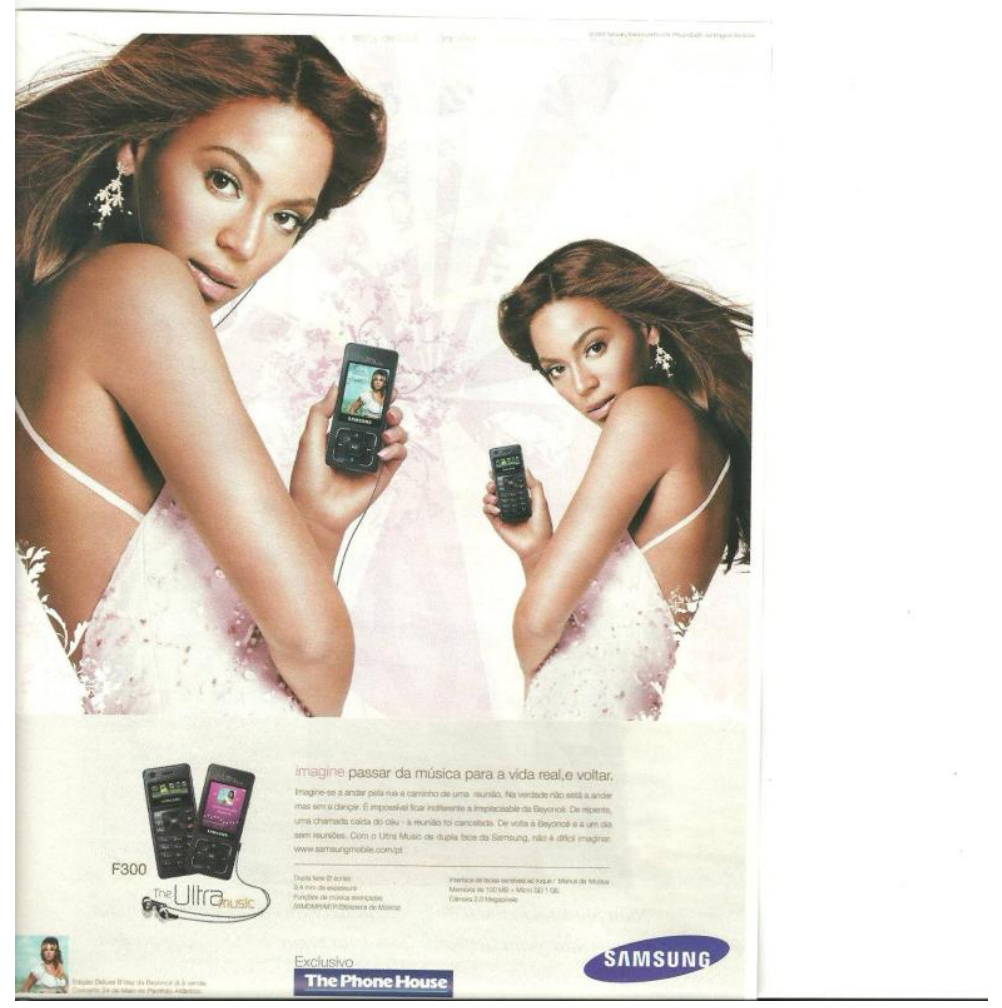

Fig. 8 - Anúncio 7: Samsung / The Phone House 
A fantasia enquanto ritual e apelo publicitário: uma proposta de análise intertextual de Susana Silva e Rui Torres

O título deste anúncio ${ }^{10}$, "Imagine passar da música para a vida real, e voltar" implica que a música se trata de uma dimensão de fantasia e descontracção, que se intercala com a realidade. Neste sentido, em vez de assumidos enquanto produto real, a música e, por inerência, o produto, são entendidos enquanto porta de acesso a um maravilhoso novo mundo colorido pela voz de Beyoncé e pelos valores artísticos que esta possa transportar.

O texto apela à imaginação, criando um cenário em que o leitor é promovido a personagem principal numa história que, pela trivialidade do quotidiano, será facilmente a sua: "Imagine-se a andar pela rua a caminho de uma reunião". Num dia habitual de trabalho, o produto proporciona uma dupla satisfação: por um lado, a música que permite a evasão, a fuga à realidade, e, por outro, o telefonema que cancela a reunião e permite retomar o prazer. Esta transformação proporcionada pelo produto, e que permite o regresso à fantasia inicial, exprime-se pela intertextualidade da expressão "De repente, uma chamada caída do céu", que designa a chegada de uma bênção. Neste contexto, o produto é assumido enquanto fetiche, ou seja, condição necessária à imaginação e, consequentemente, à satisfação. Ao dizer "Com o Ultra Music de Dupla Face da Samsung, não é difícil imaginar", o anúncio diz que, com este telemóvel, a imaginação ganha asas. Tal como o prazer.

\footnotetext{
${ }^{10}$ Anúncio inserido na revista Lux Woman, n. ${ }^{\circ}$ 76, edição de Julho 2007: 59.
} 


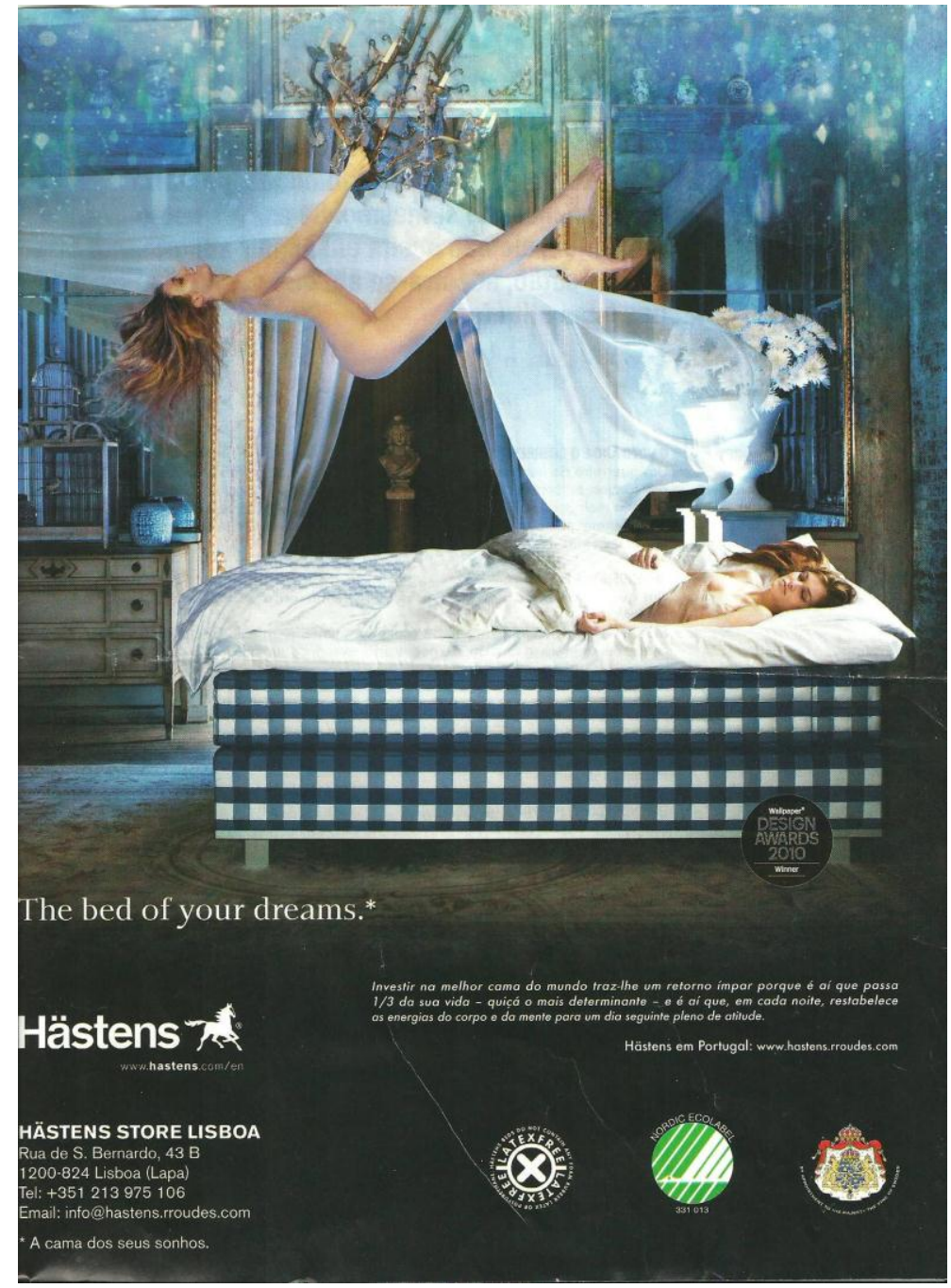

Fig. 9 - Anúncio 8: Haestens

Neste anúncio ${ }^{11}$, a imagem assume o protagonismo. Uma mulher surge deitada numa cama de design moderno mas enquadrada no ambiente luxuoso de um quarto clássico. Sobre a cama, o seu corpo nu atravessa o esvoaçar dos cortinados brancos e balança-se num candelabro, representando a leveza do sonho. O jogo de luz na parte superior do anúncio orienta o leitor no sentido da ascensão a um plano de fantasia. $\mathrm{O}$ branco dos lençóis, das cortinas e das flores simboliza a pureza que se enquadra num ambiente romântico proporcionado pelos adereços do quarto. A nudez integral traduz liberdade, mas assume também um cunho erótico, uma vez que, na sua fantasia, a mulher se encontra desperta e revelando prazer. De acordo com Chevalier e Gheerbrant, "o simbolismo do nu desenvolve-se nas duas direcções: a da pureza e a da vaidade lasciva, provocante, que desarma o espírito em benefício da matéria e dos sentidos” (1997:477).

\footnotetext{
${ }^{11}$ Anúncio inserido na revista Lux, edição de 03/05/2010: 39.
} 
A fantasia enquanto ritual e apelo publicitário: uma proposta de análise intertextual de Susana Silva e Rui Torres

O slogan "The bed of your dreams" suporta a dupla significação da palavra sonho: por um lado, o sonho associado ao estado de levitação proporcionado pelo sono; por outro lado, o sonho no sentido de ambição, de desejo.

\section{CONCLUSÃO}

Verifica-se que na publicidade o apelo intertextual à fantasia se manifesta de diversas formas. Destaca-se a presença do género literário, pelo recurso a obras e estruturas narrativas que se inscrevem nos conhecimentos do leitor, despoletando a memória e a imaginação. Expressões verbais e elementos iconográficos como génios e lâmpadas mágicas ou figuras gigantescas remetem para a magia dos objectos e para a sua capacidade de transportarem o indivíduo a um universo paralelo de soluções.

O discurso religioso fornece bases para que o indivíduo faça a leitura do intertexto, à medida dos seus conhecimentos e crenças. Noutro contexto, a implicação de referências à música e à arte, como o recurso a ícones mundialmente reconhecidos nestas áreas, estabelece elos de ligação que conferem valores de sofisticação, dinamismo e modernidade a determinados produtos e marcas. Numa perspectiva mais controversa, pode encontrar-se em alguns anúncios símbolos que apelam à fantasia sob a forma de viagem e de alucinação, suscitando uma comparação simbólica entre a publicidade e um estado de embriaguez ateado pelo desejo de evasão.

No ritual da fantasia, o produto promete mudar a vida das pessoas, remetendo para a construção de um (sempre novo) mundo à parte e para a magia de objectos feitos à medida de sonhos. O desejo é usado como estímulo à fantasia. Um desejo que ignora os limites do real, que pode servir de libertação, mas que pode também circunscrever o indivíduo num constante devaneio.

\section{REFERÊNCIAS BIBLIOGRÁFICAS}

BARTHES, R. Mitologias. Lisboa, Edições 70, 1957.

CHEVALIER e GHEERBRANT. Dicionário dos Símbolos, s.l., Círculo de Leitores, 1997. FILHO, C. M. A Linguagem da Sedução. São Paulo, Editora Perspectiva, 1988.

FITCHETT, J. "The Fantasies, Orders and Roles of Sadistic Consumption: Game Shows and the Service Encounter" in Consumption, Markets and Culture, n ${ }^{\circ} 4$, vol. 7, 2004, p. 285-306 
A fantasia enquanto ritual e apelo publicitário: uma proposta de análise intertextual de Susana Silva e Rui Torres

FREITAS, E. Taboo in Advertising. Amsterdam, John Benjamins B.V., 2008.

GUNSTER, S. "«On the Road to Nowhere»: Utopian Themes in Contemporary Auto Advertising" in The Review of Education, Pedagogy, and Cultural Studies, vol. 29, 2007, p. 211-238.

HANNIGAN, J. Fantasy City. New York, Routledge, 1998.

HOLBROOK, M.B. e HIRSCHMAN. "The experiential Aspects of Consumption: Consumer Fantasies, Feelings and Fun" in Journal of Consumer Research, vol. 9, 1982, p. 132-140.

HOUDAYER, H. "Droga e publicidade: uma visão simbólica” in Revista Famecos, n. 29, Porto Alegre, 2006, p. 99-106.

KEHL, M. R. "Publicidade, Perversões e Fobias" in Psicanálise e Cultura, 31 (46), São Paulo, 2008, p. 27-32.

LEISS W., KLINE S., JHALLY S. e BOTTERILL J. Social Communication in Advertising - Consumption in the Mediated Marketplace. Routledge, New York, 2005.

MARTIN, B. "Using the Imagination: Consumer Evoking and Thematizing of the Fantastic Imaginary” in Journal of Consumer Research, vol. 31, 2004, p. 136-149.

MUNARI, B. Fantasia. Lisboa, Edições 70, 2007.

POLLAY, R. W. "The Distorted Mirror: Reflections on the Unintended Consequences of Advertising" in Journal of Marketing, vol. 50, 1986, p. 18-36.

RICHINS, M. L. "Social Comparison and the Idealized Images of Advertising” in Journal of Consumer Research, vol. 18, 1991, p. 71-83.

SCHOUTEN, J.W. "Selves in Transition: Symbolic Consumption in Personal Rites of Passage and Identity Reconstruction” in Journal of Consumer Research, vol. 17, 1991, p. 412-425.

VOLLI, U. Semiótica da Publicidade - A criação do texto publicitário. Lisboa, Edições 70, 2003.

WILLIAMSON, J. Decoding Advertisements - Ideology and Meaning in Advertising. London, Marion Boyars Publishers, 1994.

Artigo recebido: 13/04/2011

Artigo aprovado: 17/06/2011 